\title{
Optimization And Fabrication Of Dome Shaped Crop Dryer
}

\author{
V Jagadeesh $^{1}$, Yegireddi Shireesha ${ }^{2}$, Ch Vinod Babu ${ }^{3}$, Bade Venkata Suresh ${ }^{4}$, \\ K Ch Sekhar ${ }^{5}$ \\ ${ }^{1234}$ (Assistant Professor, Department of Mechanical Engineering GMRIT, RAJAM, Srikakulam, AP, INDIA) \\ 5 (Associate Professor, Department of Mechanical Engineering Lendi Institute of Engineering and Technology, \\ Vizianagaram AP, INDIA)
}

\begin{abstract}
Drying is a technique to preserve agriculture and fish products in order to raise their value or transform them into storable or marketable items. Drying is still carried out in the traditional manner of spreading the product on the ground in the open air or, as in the cereal industry, through the use of dryers operated with conventional fuels. Main objective of this project is to design and develop solar dryer to test thermal performance for crop and fish drying. The dryer is a green house type design for multi crop drying. The economic cost of the dryer is very much affordable for poor farmers. The dryer developed can be used as substitute to electrical and mechanical dryers in semi urban and rural areas of India for drying various agricrops and fishes. It is estimated that agri-crops and fishes obtained from the solar dryer of high quality fetching more market price for the farmers.
\end{abstract}

Keywords: Solar Dryer, Optimization, Fabrication of dome, Crop Dryer, Thermal Efficiency

\subsection{Sun Drying:}

\section{Introduction}

Crop drying is a very simple, ancient skill. It is one of the most accessible and hence the most widely spread processing technology. Sun drying of fruits and vegetables is still practiced largely unchanged from ancient times. Traditional sun drying takes place by storing the product under direct sunlight. Sun drying is only possible in areas where, in an average year, the weather allows foods to be dried immediately after harvest. The main advantages of sun drying are low capital and operating costs and the fact that little expertise is required. Moreover, since sun drying depends on uncontrolled factors, production of uniform and standard products is not expected. The quality of sun dried foods can be improved by reducing the size of pieces to achieve faster drying and by drying on raised platforms, covered with cloth or netting to protect against insects and animals

\subsection{Need For Solar Drying:}

Due to the current trends towards higher cost of fossil fuels and uncertainty regarding future cost and availability, use of solar energy in food processing will probably increase and become more economically feasible in the near future. Solar dryers have some advantages over sun drying when correctly designed. They give faster drying rates by heating the air to $10-30^{\circ} \mathbf{c}$ above ambient, which causes the air to move faster through the dryer, reduces its humidity and deters insects. The faster drying reduces the risk of spoilage, improves quality of the product and gives a higher throughput, so reducing the drying area that is needed

\subsection{Design Principle of Solar Dryer:}

The principle that lies behind the design of solar dryers is as follows: in drying relative and absolute humidity are of great importance. Air can take up moisture, but only up to a limit. This limit is the absolute (maximum) humidity, and it is temperature dependent. When air passes over a moist food it will take up moisture until it is virtually fully saturated, that is until absolute humidity has been reached. But, the capacity of the air for taking up this moisture is dependent on its temperature.. If air is warmed, the amount of moisture in it remains the same, but the relative humidity falls; and the air is therefore enabled to take up more moisture from it's surrounding. To produce a high-quality product economically, it must be dried fast, but without using excessive heat, which could cause product degradation. Drying time can be shortened by two main procedures: one is to raise the product temperature so that the moisture can be readily vaporized, while at the same time the humid air is constantly being removed. The second is to treat the product to be dried so that the moisture barriers, such as dense hydrophobic skin layers or long water migration paths, will be minimized

\subsection{Bamboo:}

\section{Materials Used In Fabrication Of Dryer}

Bamboo remained as the poor man's timber in spite of being a high performance light weight functionally graded composite and with almost no parallel, particularly in delivering a given performance for 
unit cost. A substantial body of data on bamboo has been generated the world over in the past four decades and has painted a picture that is far from being sharp. Extensive basic experimentation is still the need of the hour that hopefully would enable us to see the rhythm in the huge diversity of the properties of bamboo, bordering on near randomness by making the picture sharp. The modern engineering designers would then be able to more confidently begin to accept bamboo as a green engineering material and eventually as the most dependable partner in our fight against global warming.

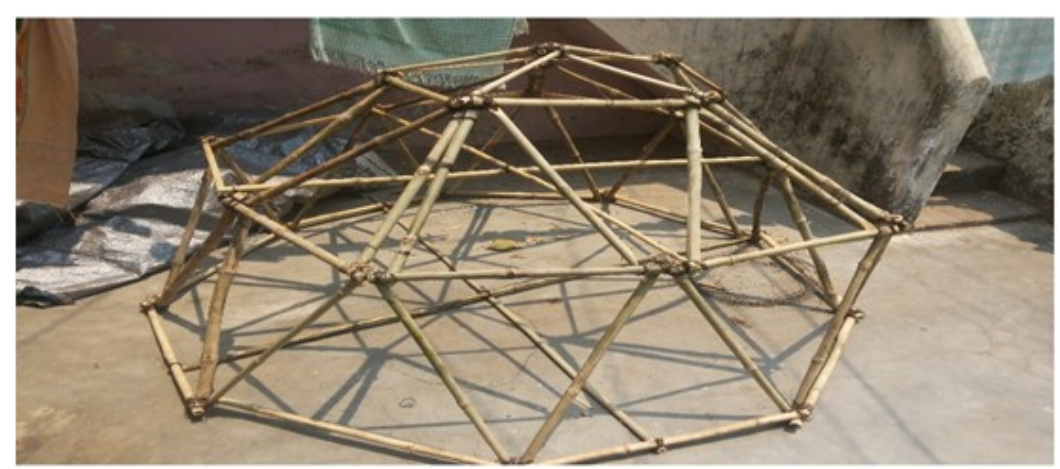

Fig 2.1 Dome construction at initial stage

Establishment of bamboo as a Modern Building Material can alone generate the necessary massive demand to make the bamboo plantations remunerative and greening of degraded lands in economically viable manner. This will trigger a sustainable growth for the rural economy and also help ease global warming by reduction of the use of cement and steel.

\begin{tabular}{|c|c|c|c|c|}
\hline MILD STEEL & $\begin{array}{l}\text { ULTIMATE } \\
\text { STRENGTH= } \\
\text { 410MPA }\end{array}$ & $\begin{array}{l}\text { YIELD } \\
\text { STRENGTH= } \\
\text { 250MPA }\end{array}$ & $\begin{array}{l}\text { YOUNG'S } \\
\text { MODULUS=200 } \\
\text { GPa }\end{array}$ & $\begin{array}{l}\text { DENSITY=7850 } \\
\mathrm{Kg} / \mathrm{m}^{\wedge 3}\end{array}$ \\
\hline $\begin{array}{l}\text { CONCRETE } \\
\text { (GRADE M 30) }\end{array}$ & $\begin{array}{l}\text { TENSILE } \\
\text { STRENGTH=3.8 } \\
\mathrm{MPa}\end{array}$ & $\begin{array}{l}\text { COMPRESSIVE } \\
\text { STRENGTH=38 } \\
\mathrm{MPa}\end{array}$ & $\begin{array}{l}\text { YOUNG'S } \\
\text { MODULUS=27 } \\
\text { GPa }\end{array}$ & $\begin{array}{l}\text { DENSITY }=2400 \\
\mathrm{~g} / \mathrm{m}^{\wedge} 3\end{array}$ \\
\hline ВАМВОО & $\begin{array}{l}\text { TENSILE } \\
\text { STRENGTH=120 } \\
\text { MPa }\end{array}$ & $\begin{array}{l}\text { COMPRESSIVE } \\
\text { STRENGTH=55 } \\
\mathrm{MPa}\end{array}$ & $\begin{array}{l}\text { YOUNG'S } \\
\text { MODULUS=140 } \\
\text { GPa }\end{array}$ & $\begin{array}{l}\text { DENSITY=700K } \\
\mathrm{g} / \mathrm{m}^{\wedge} 3\end{array}$ \\
\hline
\end{tabular}

Table 2.1 Strength of different materials

\subsection{Green House Cover}

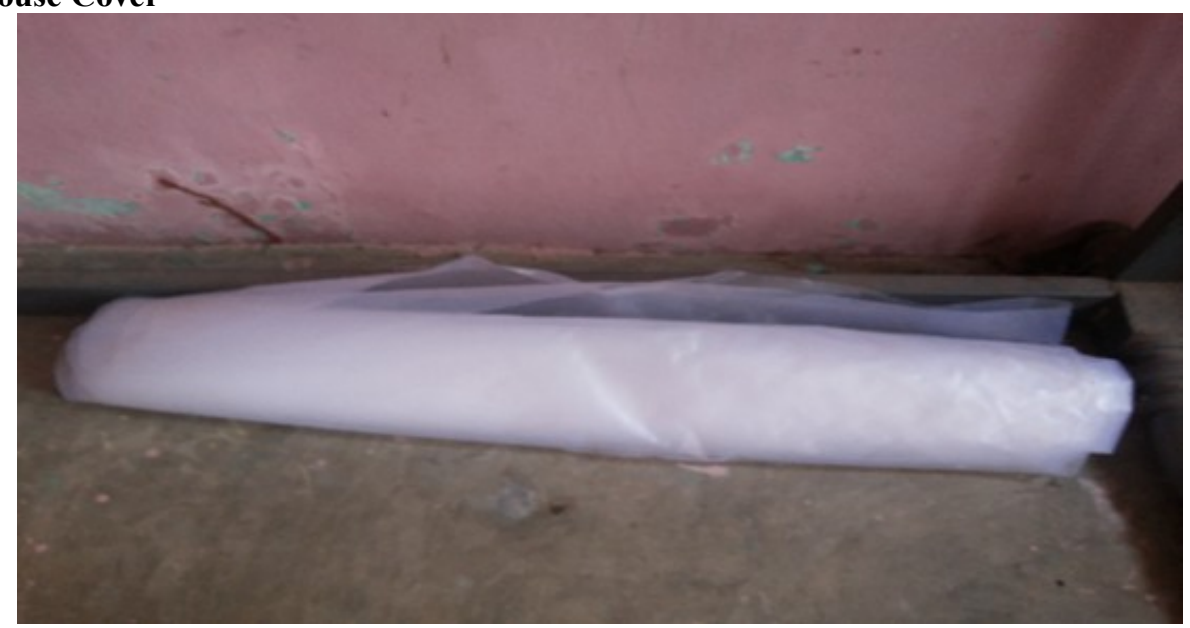

Fig 2.2 Polyethylene green house cover 
The most common greenhouse glazing materials are glass, rigid plastics and plastic films

\subsection{Glass}

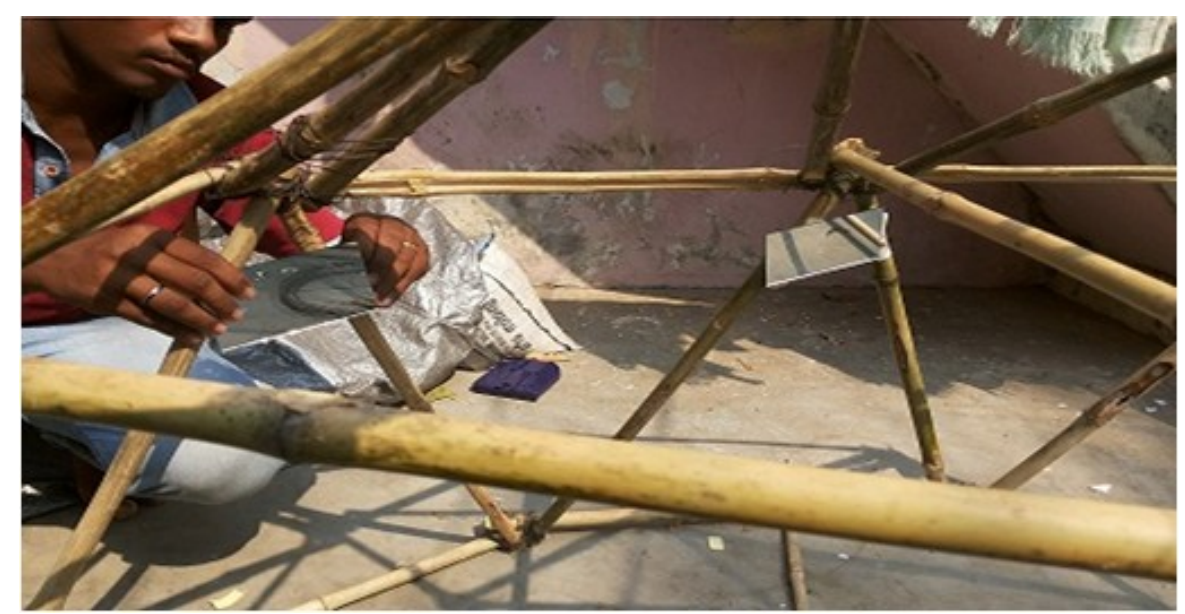

Fig 2.3 Mirrors

Glass has the highest light transmission, lasts the longest (30-plus years) and is the most expensive. Tempered or laminated glass is recommended because it is stronger allowing for fewer support bars, and it increases the safety for people working underneath in case of breakage (check the local building code). Most glass greenhouses are clad with a single layer resulting in a relatively high heat transfer coefficient.

\subsection{Rigid Plastics}

Rigid plastics (e.g., polycarbonate and acrylic) are less expensive than glass and last seven to 20 years. They are usually manufactured as twin-walled sheets. The air space between the two walls acts as an insulator. Light transmission through rigid plastics is very good, although it usually decreases over time as the plastics age and turn yellow due to the amount of UV radiation contained in sunlight. The large sheets are much lighter than glass and require fewer support bars to attach them to the greenhouse frame. However, these rigid panels are not so easy to install on curved roof.

\subsection{Polyethylene}

This is the cheapest material having $88 \%$ transitivity and they are widely used for green house coverings. These are resistant against UV radiation.

\subsection{Insulating Material}

Thermocoal:

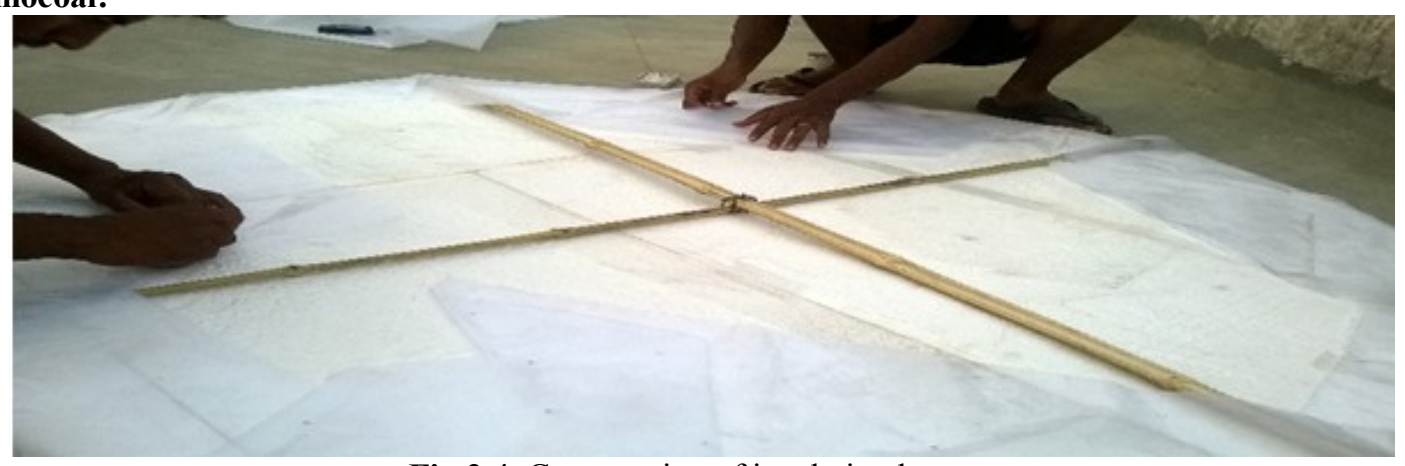

Fig 2.4. Construction of insulating bottom

Thermo coal used as insulating material under the platform to resist heat flow to outside atmosphere from the dome cabinet. It is easily available and cheapest in all type of insulating materials. It has the temperature insulating range of -20 to $80^{\circ} \mathrm{C}$ which is very much suitable to our design. 


\section{Experimentation And Thermal Analysis Of Solar Crop Dryer}

\subsection{Experimentation}

Experiments were conducted for 3 days in the months of march 2014 under the meteorological conditions of Rajam, Andhra Pradesh, India. Fresh green chillies obtained from the market was used to study the performance of drier. Initial moisture content was calculated by taking 1000 grams of samples taken from the drier. Solar intensity, dry weight, dryer temperature, ambient temperatures and relative humidity were measured every one hour interval till the end of drying.

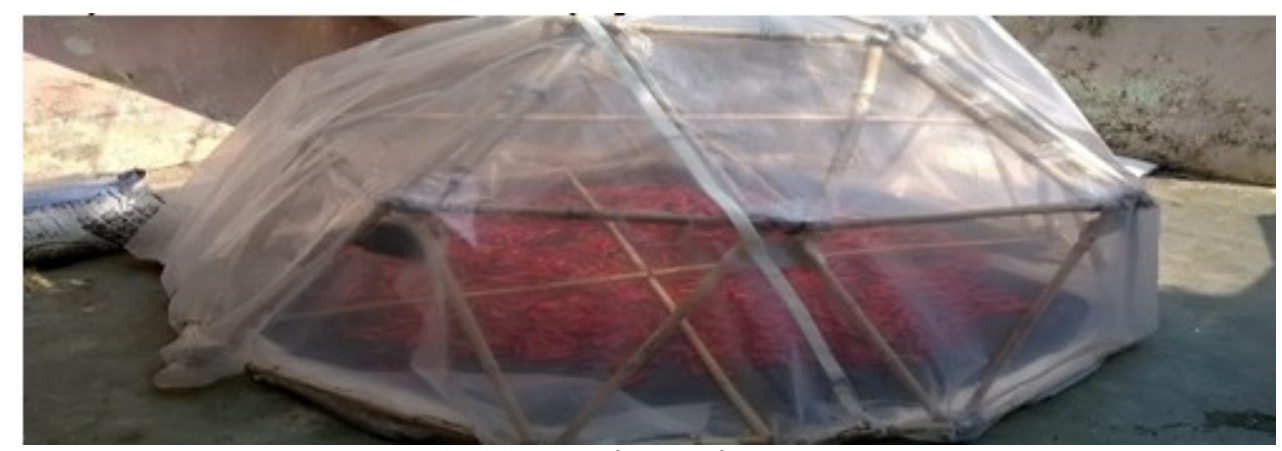

Fig 3.2 Experimentation process

\subsection{Observations}

\begin{tabular}{|c|c|c|c|}
\hline $\begin{array}{c}\text { (PRODUCT-CHILLI) } \\
\text { 1000gms }\end{array}$ & $\begin{array}{c}\text { TEMPERATURE } \\
\text { (Ambient) }\end{array}{ }^{\circ} \mathrm{C}$ & $\begin{array}{c}\text { WEIGHT } \\
\text { (gms) }\end{array}$ & $\begin{array}{c}\text { CUMULATIVE } \\
\text { MOISTURE } \\
\text { REMOVED } \\
(\%)\end{array}$ \\
\hline DAY 1 & 34 & 860 & 14 \\
\hline DAY 2 & 32 & 675 & 33.5 \\
\hline DAY 3 & 33 & 470 & 43 \\
\hline
\end{tabular}

Table 3.1 Observations recorded in ambient atmosphere

\begin{tabular}{|l|l|l|l|}
\hline $\begin{array}{l}\text { (PRODUCT-CHILLI) } \\
\text { 1000gms }\end{array}$ & $\begin{array}{l}\text { TEMPERATURE } \\
\text { (cabin) })^{\circ} \mathrm{C}\end{array}$ & $\begin{array}{l}\text { WEIGHT } \\
(\mathrm{gms})\end{array}$ & $\begin{array}{l}\text { CUMULATIVE } \\
\text { MOISTURE } \\
\text { REMOVED } \\
(\%)\end{array}$ \\
\hline DAY 1 & 58 & 800 & 20 \\
\hline DAY 2 & 57.4 & 510 & 49 \\
\hline DAY 3 & 59 & 280 & 72 \\
\hline
\end{tabular}

Table 3.3 Observations recorded inside dome

\section{Experimental Analysis}

$\mathrm{Wf}=$ weight of sample after drying

$\mathrm{Wi}=$ weight of sample before drying

$\mathrm{Wm}=$ Moisture content removed

A = Area of collecting surface

I $=$ Solar Irradiance

$\mathrm{hfg}=$ Latent heat of vaporization of water

$\Delta \mathrm{T}=$ Time taken

$$
\begin{aligned}
& =280 \mathrm{~g} \\
& =1000 \mathrm{~g} \\
& =720 \mathrm{~g} \\
& =1.35 \mathrm{~m}^{\wedge} 2 \\
& =577 \mathrm{w} / \mathrm{m}^{\wedge} 2 \\
& =2260 \mathrm{kj} / \mathrm{kg} \\
& =30 \mathrm{hrs}
\end{aligned}
$$




\subsection{Measurements}

Total Instantaneous Global Solar irradiance was measured by using portable Solar Power meter with an uncertainty of $\pm 10 \%$. The temperature and humidity inside and outside the drying chamber was measured with digital thermo hygrometer. Air velocity at drier exit was measured by using portable anemometer having $\pm 0.5 \%$ uncertainty. A digital electronic balance of $5 \mathrm{~kg}$ capacity having an uncertainty of $\pm 0.1 \%$ was used to weigh the samples

\section{Thermal Analysis}

\subsection{Moisture Content Removal}

Initial (Wi) and final mass (Wf) at time (t) of samples were recorded using electronic balance and repeated every $1 \mathrm{~h}$ interval till the end of drying. The percentage moisture content was determined by using the following formula. Moisture content on wet basis ( $\mathrm{M}_{\mathrm{wb}}$ ) was calculated using the following equation.

Moisture content removed:

$\mathrm{Mwb}=(\mathrm{Wi}-\mathrm{Wf}) / \mathrm{Wi}$

Where,

$\mathrm{Wi}=$ weight of sample before drying, gram

$\mathrm{Wf}=$ weight of sample after drying, gram.

$\mathrm{M} \mathrm{wb}=$ Moisture content removed on wet basis. (gram)

\subsection{Thermal Anlaysis of Drier}

The amount of heat required to evaporate the moisture inside the product is called as drying efficiency. In case of solar dryer, total available solar radiation on collector surface of the dryer gives the total heat input. This thermal efficiency of bamboo drier was estimated using the equation.

Thermal efficiency of drier:

$\eta$ th $=\mathrm{mw}$ hfg $/(\mathrm{AI})$

Where: $\eta_{\text {th }}$ drier thermal efficiency, $m_{W}$, the mass of water evaporated in time $t=(\mathrm{Wi}-\mathrm{Wf}) \mathrm{kg}$;

$\mathrm{h} f \mathrm{~g}$, the latent heat of vaporization of water $(\mathrm{kJ} / \mathrm{kg})$; A, the area of solar bamboo drier $\left(\mathrm{m}^{2}\right)$;

I, solar irradiance $\left(\mathrm{W} / \mathrm{m}^{2}\right)$

\subsection{Drying Rate}

The drying was carried out by loading the weighted chillies in dryer from morning 8:00 am to 18:00 $\mathrm{pm}$. The chilies were dried up to the final moisture content of $10 \%$ (w.b.). The drying rate $(\mathrm{g} / \mathrm{h} / 100 \mathrm{~g}$ of dry weight) of sample during drying period was determined as follows,

Drying rate $(\mathrm{D} . \mathrm{R})=\Delta \mathrm{W} / \Delta \mathrm{T}$

Where, $\quad \Delta \mathrm{W}=$ weight loss in one day interval, $\quad \Delta \mathrm{T}=$ difference in time reading $(\mathrm{h})$

\section{Results}

Solar radiation intensity, Relative humidity and temperature inside the collector were measured with time of day in the interval of one hour were plotted. About 1000 gram of fresh green chillies with $90 \%$ average initial moisture content was taken for study and loaded in the drying chamber of solar bamboo dryer. The variation of solar radiation with time is shown in the figure. During the experiments, the sky was clear and the maximum solar radiation observed was $1055 \mathrm{~W} / \mathrm{m}^{2}$.

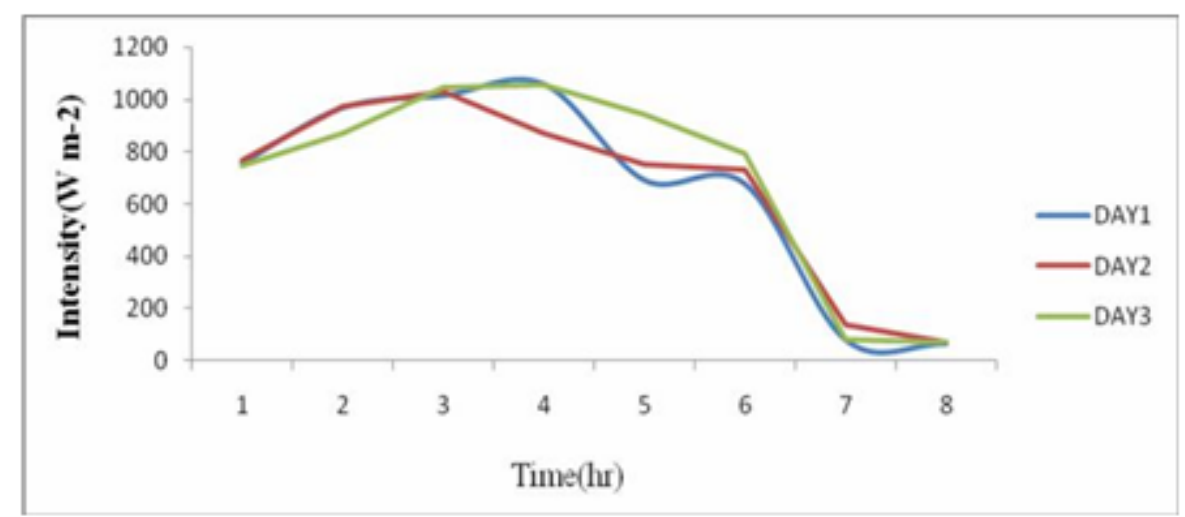

Graph 4.1 Variation of solar intensity with time: 
The variation of ambient and drier temperature was illustrated in the maximum temperature observed inside the drying chamber on day 1 is $58^{\circ} \mathrm{C}$, day 2 is $57.4^{\circ} \mathrm{C}$ and day 3 is $59.2^{\circ} \mathrm{C}$. The maximum ambient temperature observed inside the drying chamber on day 1 is $34^{\circ} \mathrm{C}$, day 2 is $32.8^{\circ} \mathrm{C}$ and day 3 is $33.0^{\circ} \mathrm{C}$.

Humidity varies from 18.0 to $52.8 \%$ inside the solar dryer whereas outside humidity varies from 22.6 to $39.5 \%$. Overall humidity inside the dryer was maximum as compare to normal condition.

The average moisture content of the chilli was reduced from about $90 \%$ (w.b.) to about $18 \%$ (w.b.) in 30 hours in the solar bamboo drier. The moisture reduction during the first, second and the third day of drying was found to be about $20 \%, 49 \%$ and $72 \%$ respectively. The thermal efficiency of the solar bamboo drier was calculated using the "Eq.(2)". The maximum efficiency of the drier was found to be around $20 \%$. The maximum drying rate of the drier was found to be around $24 \mathrm{~g} / \mathrm{hr}$ and the minimum was $13.5 \mathrm{~g} / \mathrm{hr}$ with an average efficiency of $19 \mathrm{~g} / \mathrm{hr}$.

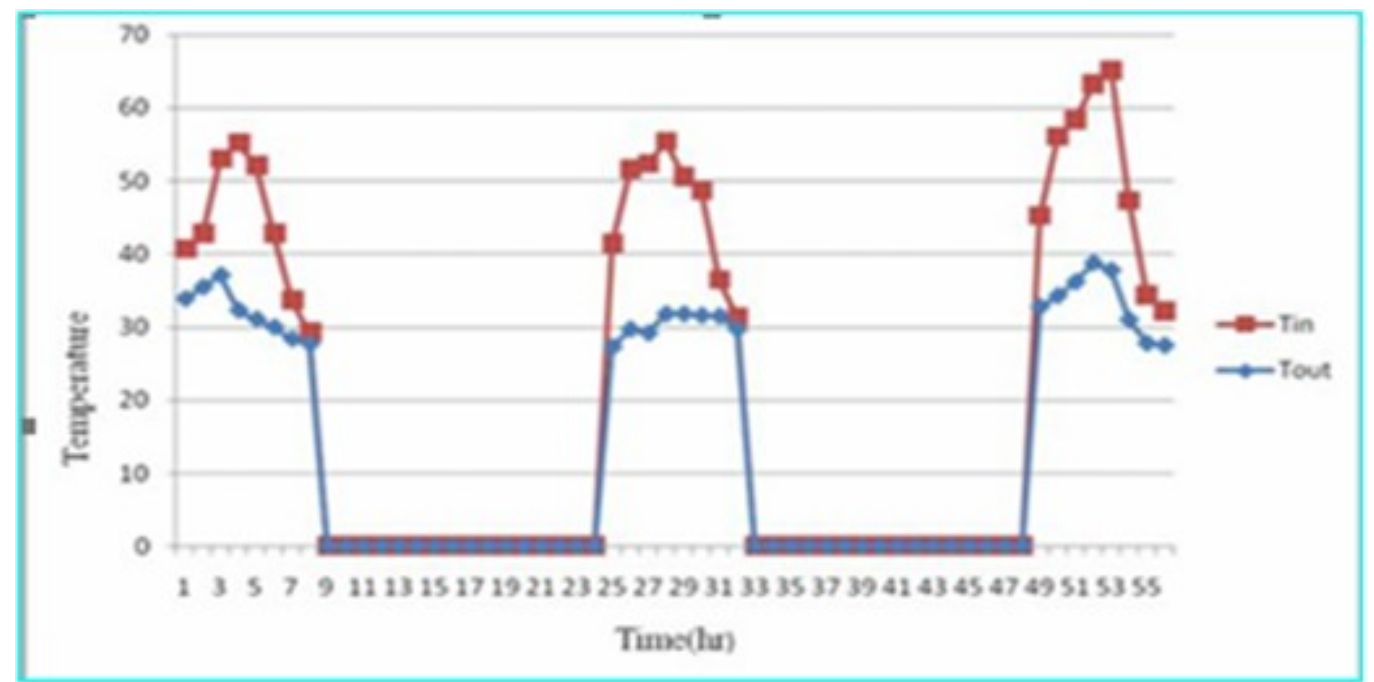

Graph 8.2 Variation of temperature with time

\section{Conclusion}

From the experimental work conducted for the drying of chillies in low cost solar bamboo drier, then following conclusions are drawn:

The chilly can be dried from an initial moisture content of $90 \%$ (w.b.) to the required moisture level of $18 \%$ (w.b.) in 30 hours. The mean thermal efficiency of the solar drier during the performance test was around $20 \%$. The average drying rate of the solar dryer was around19 $\mathrm{g} / \mathrm{hr}$. The payback period of the solar dryer could be recovered within one to two month. Solar dryer is suitable for domestic drying of agricultural crops up to $5 \mathrm{~kg}$ capacity. The dryer can be used efficiently during sunny weather conditions and there is no requirement of electricity source for drying.Also, the chillies obtained from the solar bamboo drier are of high quality, fetching more market price for the farmers. It can be concluded that this type of solar bamboo dryer is more suitable for the farmers for producing high quality product. It can therefore be used in rural areas as the source of renewable energy.

\section{Acknowledgements}

The satisfaction that accompanies the successful completion of any task would be incomplete without introducing the people who made it possible and whose constant guidance and encouragement crowns all efforts with success.

We express our sincere gratitude to the management of GMR Institute of Technology, Rajam. We are highly indebted to them. for their guidance and encouragement to complete this work successfully

\section{References}

[1]. Ferreira, A.G., Maia, C.B., Cortez, M.F.B., Valle, R.M., 2008. Technical feasibility assessment of a solar chimney for food drying. Solar Energy

[2]. Forson, F. K., Nazha,M. A. A.\& Rajakaruna, H. (2007).Modelling and experimental studies on a mixed- mode natural convection solar crop-dryer. Solar Energy,81, 346-357.

[3]. Gallali, Y.M., Abujnah, Y.S., Bannani, F.K., 2000. Preservation of fruits and vegetables using solar dryer: a comparative study of natural and solar drying, III: chemical analysis and sensory evaluation data of the dried samples (grapes, figs, tomatoes and onions). Renewable Energy19 (1-2), 203-212.

[4]. Hossain, M. A., J. L. Woods, and B. K. Bala. 2007. Single-layer drying characteristics and color kinetics of red chillis. Food Science and Technology, 42 (11): 1367-1375. 
[5]. Hossain, M.A., Bala, B.K., 2007. Drying of hot chilli using solar tunnel drier. Solar Energy 81, 85-92.

[6]. Jain, D., Tiwari, G.N., 2004. Effect of greenhouse on crop drying under natural and forced convection II. Thermal modeling and experimental validation. Energy Conversion and Management 45, 2777-2793

[7]. Kumar, A., Tiwari, G.N., 2006. Thermal modeling of a natural convection greenhouse drying system for jaggery: an experimental validation. Solar Energy 80, 1135-1144

[8]. Kooli, S., Fadhel, A., Farhat, A., Belghith, A., 2007. Drying of red pepper in open sun and greenhouse conditions: mathematical modeling and experimental validation. Journal of Food Engineering 79 (3), 1094-1103.

[9]. Murthy Ramana, M.V., 2009. A review of new technologies, modes and experimental investigations of solar dryers. Renewable and Sustainable Energy Reviews 13, 835-844

[10]. Ponting, J. D., and D. M. McBean. 1970. Temperature and dipping treatment effects on drying rates and drying times of grapes, prunes and other waxy fruits. Food technology, 24 (12):85-88. 